\title{
The Effect of Human Capital, Social Capital,and Competency on Women Entrepreneur Success in Surabaya Indonesia
}

\author{
S Mujanah ${ }^{1}$, A Kusmaningtyas ${ }^{2}$, Candraningrat ${ }^{3}$ \\ \{Sitimujanah@untagsby.ac.id $\left.{ }^{1}\right\}$ \\ ${ }^{1,2}$ Universitas 17 Agustus 1945 Surabaya, Indonesia \\ ${ }^{3}$ Institut Bisnis dan Informatika Stikom Surabaya, Indonesia
}

\begin{abstract}
The purpose of this study is to analyze the influence of Human Capital, Social Capital and Entrepreneurial Competence on the Success of Woman Entrepreneurs in the City of Surabaya Indonesia. This study uses a quantitative approach to SPSS statistical software. This is based on empirical theory that correlates with the variables that exist in this study, which then data is collected by distributing questionnaires. The sample used in this study is 85 respondents which consisted of female entrepreneurs who were registered into Department of Industry Surabaya, Indonesia. the results of this study indicate that human capital, social capital, and competency simultaneously have a significant effect on the success of woman entrepreneurs, while partially competence has no significant effect on the success of woman entrepreneurs, but human capital and social capital have a significant effect on the success of female entrepreneurs.
\end{abstract}

Keywords:Human Capital; Social Capital; Entrepreneurial Competence; and Women Entrepreneurial success.

\section{Introduction}

Various forms of intangible assets including knowledge, trust, managerial ability, ability to propose new ideas, capacity to innovate, reputation to consumers and the quality of a product are very necessary, often entrepreneurial success is due to always paying attention to intangible assets in the form of knowledge and relationship behavior patterns or those called human capital and social capital [1].

Human capital is the economic value of humans that is relevant to expertise in knowledge, ideas, energy, and commitment. In business activities, human capital has advantages that cannot be compared with other production factors [2]. Another aspect that can be revealed in running a business is social capital, where the personality of the entrepreneur is behind the environment in which he lives. Although knowledge greatly helps success in their endeavors, environmental factors also affect one's unique personality [3].

Instead of Human Capital, Social capital is also needed in business success. Social capital is defined as a personal description of social relations arranged in the structure of society [4]. Social capital is defined as a personal description of social relations arranged in the structure 
of society [4]. Social capital provides a construction principle regarding the meaning of trust, togetherness, tolerance, and participation related to values or the spirit of entrepreneurship. Community social capital such as trust, mutual cooperation, networking, and altruistic attitudes have a major impact on business development, such as fostering community trust manifested in honest, orderly, and cooperative behavior based on shared norms. In business activities, social capital can be useful as a success of business activities with the values of cooperation in it. The social capital capabilities possessed by entrepreneurs encompass good reputation and broad social networks. This ability can be obtained through social competence. As mentioned by Markman[5] that Social competence is seen as emotional intelligence that aims to help entrepreneurs work together with employees, sources of funds, potential customers and the formation of work alliances.

In addition to Human Capital and Social Capital Entrepreneurial competencies are also important, this is in accordance with what Mujanah[6] said that's competence can improve its performance. Human capital research, Social Capital on business success has been done [7], but in this study will look for its influence on the success of entrepreneurial women.

\section{Theoretical Review}

\subsection{Human Capital}

Human capital is a capability, expertise, knowledge, and skill possessed by humans and makes them the capital or assets of a company. When a company considers that an employee is a capital, then the company will get a greater profit than the company only considers employees as resources.

Gaol[8] also said that by considering employees as the capital where they have the ability, expertise, and skills, the people (employees) who work in a company are able to run other resources such as money, machinery, materials, data, and information.

Becker[9] introduces the concept of human capital in economics. Human capital plays a very strategic role in supporting the competitiveness of a country or region. Foreign investment into Southeast Asia led to the assimilation of new technology and at the same time increased productivity, and this occurred in business sectors with high growth rates such as the textile and apparel industry, leather, and machinery and equipment [10], this is aline with the results of Nugraha[11] that human capital in the company motivates employee itself to have a good impact and improve the company's performance.

H1: Human Capital Influences the Success of Entrepreneurship

\subsection{Social Capital}

Social Capital refers to the basis of social organization, for example, trust (norms), norms and social networks that require the implementation of activities to be more synchronized, and community members can be involved and cooperate effectively and efficiently in realizing shared goals, and can have an impact on productivity individually or group [12].

Bourdieu[13] said that social capital is an aggregate of actual or potential resources that are bound to create long-term networks so as to institutionalize mutually beneficial acquaintance [14]. According to Cox[15], social capital is a series of processes of human relations that are sustained by networks, social norms, and beliefs that enable efficient and effective coordination and cooperation for mutual benefits and virtues. Hasbullah[16], social capital 
emphasizes a broader dimension, that is, everything that makes communities allied to achieve goals.

Social capital in society creates a variety of social obligations, the climate of mutual trust, carries information channels, and sets norms, and social sanctions for members of the community [17].

The research conducted by Liu and Fauzan[18], [19]Found that a social capital structural dimension was influenced on employee performance in the e-business area. That in developing a robust information system, one of the dimensions of social capital has a high enough effect on employee performance both substantially and symbolically. According to Fukuyama[20] that the power of human social capital becomes the glue for healthy development for economic life.

H2: Social Capital affects the success of Entrepreneurs

\subsection{Entrepreneur Competence}

Competence is the ability to carry out or carry out a work based on skills and knowledge and is supported by a work attitude that is demanded of the work performed. According to Wibowo[21], competency is the basic foundation of people's characteristics and indicates how to behave or think, equate situations, and support for a long period of time.

There are three main components in the formation of competencies, namely the knowledge possessed by a person, the abilities and behavior of an individual [22]. Knowledge is information that is owned by an employee or employee to carry out their duties and responsibilities in accordance with their respective fields.

In line with the opinion of Suparno[23] that "competency refers to an individual's knowledge, skills, abilities or personality characteristics that directly influence job performance". That is, competence has aspects of knowledge, skills or skills and abilities that affect employee performance.

According to the results of his research [6] that Entrepreneurial Competence affects entrepreneurial performance because an entrepreneur needs skills, knowledge and behavior in managing his business to be successful. Likewise from the results of the research of Ahmad and Sihombing[24], [25] which show that the stronger an entrepreneur's competency in a conducive vs. competitive environment, the more entrepreneurial financial success. Other results show like research

H3: Competence affects the success of entrepreneurship

\subsection{Entrepreneurial success}

According to Holbeche[26], success is the right achievement with something that is a goal, fame, prosperity. Success is centered on extensive planning and design, assessment of the right situation, accurate anticipation of the resistance to change and the skills needed to overcome this resistance. The emphasis is on intention, stability and returns to equilibrium for business success.

Richard Branson said that Success is the satisfaction of doing something for yourself and can motivate others to work with you, to realize that success. Success is about fun, innovation, creativity, where the value is far greater than money.

Based on the theoretical study above, the theoretical framework in this study is illustrated in the figure as follows: 


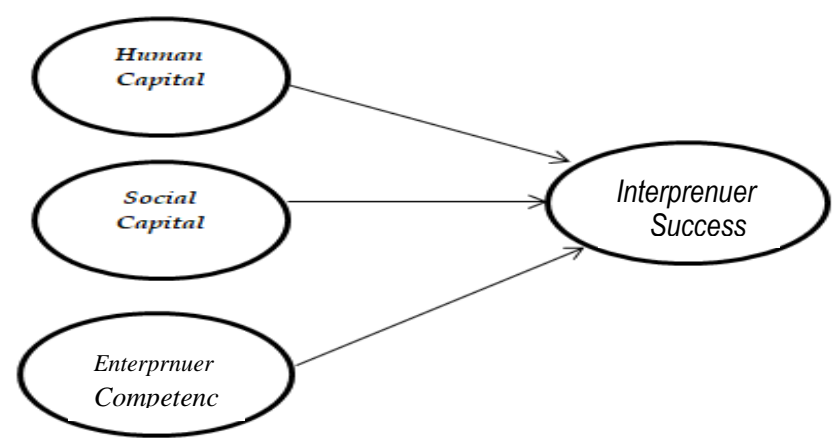

Figure 1: Theoretical Framework

\section{Method}

This research was conducted with a quantitative approach with causality and descriptive format with the aim of testing the hypothesis of the relationship between independent variables and the dependent variable.

The variables in this study consist of human capital which according to Mayo[27] human capital is 1) personal capabilities, 2) professionals and technical know-how, 3) experience, 4) the network and range of personal contacts, and 5) the value and attitudes that influence actions, and Variables of social capital measured by several dimensions such as 1) various kinds of social obligations, 2) creating a climate of mutual trust, 3) carrying information channels, and 4) establishing norms, and 5) sanctions social for the members of the community as stated by Coleman[17], while the competence variable consists of knowledge, abilities, and behavior of individuals [22].And the success of entrepreneurship can be measured by achieving goals correctly, fame, and prosperity [26].

This research population in this research is the entrepreneurs in the Surabaya city, and sample that is taken in the research is the purposive sampling technique which is determined that the women's entrepreneurs and have a year of business among 3 (three) years registered in the department of industry in the city of Surabaya in this 85 identifications.

The data analysis technique in this research using Software SPSS version 24, before the analysis, data has been validity test to know the ability of instruments in measuring research variables, and reliability test to know the consistency of respondents in answering questions. Furthermore, to know the amount of the influence of human capital, social capital and competence on success woman Enterprenuer performed by multiple regression analysis. Hypotheses test do with t-test to know the influence of variable dependent to variable independent for partial and F-test used to prove the amount of simultaneous effect of dependent variables on the independent variable.

\subsection{Result and Discussion}

Before further analysis, it is necessary to test the quality of the data, which consists of Validity and Reliability Tests, and the result is that all question items show validity shown by the value of Correlation above 0,30, and the Reliable test has indicated that all variables get Combrach numbers above 0.6 so that they are declared reliable. 


\subsection{Coefficient Correlation Analysis}

Coefficient correlation is used to determine the relationship between variables in the study, and the results can be seen in table 1 .

Table 1. Determinant Test Results (R2)

\begin{tabular}{lllll}
\hline Model Summary & & & & \\
\hline Model & $\mathrm{R}$ & $\mathrm{R}$ Square & Adjusted R Square & Std. Error of the Estimate \\
\hline 1 &, $810^{\mathrm{a}}$ &, 656 &, 634 & 1,21735 \\
\hline
\end{tabular}

a. Predictors: (Constant), Human Capital, Social Capital and Competent

b. Dependent Variable: Interprenuer Success

Source: The results of the study were processed using SPSS 23

Based on table 1, it is known that the value of $\mathrm{R}$ is 0.810 , this means that the relationship of the variables Human Capital, Social Capitan, and Competence as simultaneously strong relation on the Interprenuer Success variable. And the value of $\mathrm{R}^{2}$ is 0.656 means that the role of Human Capital, Social Capital, and Competence on entrepreneurial success is $65.6 \%$ while the remaining $36.6 \%$ is determined by other variables outside of this study.

\subsection{Multiple Linear Regression Analysis}

The data analysis model used in this study is multiple regression analysis, and the results can be seen from table 2 and the equation as follows:

Table 2. Multiple Linear Regression Analysis Test Results

\begin{tabular}{|c|c|c|c|c|c|c|}
\hline \multicolumn{7}{|c|}{ Coefficients $^{\mathrm{a}}$} \\
\hline \multirow[b]{2}{*}{ Model } & & \multicolumn{2}{|c|}{ Unstandardized Coefficients } & \multicolumn{2}{|c|}{$\begin{array}{l}\text { Standardized } \\
\text { Coefficients }\end{array}$} & \multirow[b]{2}{*}{ Sig. } \\
\hline & & $\overline{\mathrm{B}}$ & Std. Error & Beta & $\mathrm{T}$ & \\
\hline \multirow[t]{4}{*}{1} & (Constant) & $-3,194$ & 2,906 & & $-1,099$ & 277 \\
\hline & Human Capital & 348 &, 120 &, 315 & 2,905 & ,006 \\
\hline & Social Capital & 572 & 138 & 431 & 4,143 &, 000 \\
\hline & Kompetence & 180 & ,094 & 226 & 1,907 &, 063 \\
\hline
\end{tabular}

a. Dependent Variable: Woman Enterprenuer Success

Source: Data processing multiple linear regression analysis using SPSS

Regression Equations can be arranged as follows:

$$
\begin{aligned}
& Y=a+\left(b_{1} x_{1}\right)+\left(b_{2} X_{2}\right)+\left(b_{3} X_{3}\right)+e \\
& Y=-3,194+0,348 X_{1}+0,572 X_{2}+0,180 X_{3}+e
\end{aligned}
$$

The constant value (a) in this equation is $-3,194$, it's mean that if the value of Human Capital, Social Capital and Competence is zero (0), then entrepreneurial success is less than expected, namely $-3,194$.

Regression coefficient value or $b_{1}$ shows the regression coefficient number for $b_{1} X_{1}$ is 0.348 , its mean that there is a direct influence between Human Capital and entrepreneurial success, this means that if the value of Human Capital rises by 1 unit, then the value of 
Entrepreneur success will increase by 0.348 units with the assumption that other independent variables are constant.

The regression coefficient or $\left(b_{2}\right)$ for Social Capital is 0.572 , indicating a direct influence between social capital and the entrepreneurial success variable. if the Social Capital variable value increases by 1 unit, then the value of the entrepreneurial success variable will increase by 0.572 units assuming that the other independent variables are constant.

The value of the regression coefficient of $b_{3}$ or Competencies is 0,180 , its shows that there is a direct influence between Competence and the success of women Entrepreneur. This means that if entrepreneurial competencies increase by 1 unit, then the value of Entrepreneurial Success will increase also by 0.180 units assuming that the other independent variables are constant.

\subsection{Hypothesis testing}

Table 2 shows the results of the t-test shows the partial effect within two variable. The value of t-test of Human Capital to Success Entrepreneur is equal 2.905, it's mean that the Human Capital significantly effect on Success Entrepreneurial. So the Hypothesis 1 stated is accepted. This means that human capital should be considered because it can support the entrepreneur in achieving success. This shows that the results of this study support the results of research by [8]-[11] which states that human capital in a company motivates employees to have a good impact and improve company performance.

While the results of the t-test for the Social Capital variable on entrepreneurial success amounted to 4,143 with Probability significant as 0.00 less than 0.05 , it's mean that $\mathrm{H}-2$ which states that Social Capital has a significant effect on Entrepreneurial Success is accepted. The results of this study support what has been examined by several researchers [17]-[20] which state that there is an influence of social capital structural dimensions on employee performance in the e area -business and social capital dimensions have a high enough influence on employee performance both substantially and symbolically.

The result of t-test for the effect of Competence on Entrepreneurial Success shows a number of 1.907 or a significant probability of 0.63 its greater than 0.05 , which means that competence has no significant effect on entrepreneurial success, so H-3 is rejected. This shows that the results of this study do not support the research [6], [24], [25] which result in Entrepreneurial Competence influencing entrepreneurial performance because indeed an entrepreneur needs skills, knowledge, and behavior in managing his business in order to be successful. However, in this study the role of competence is not likely because it is more dominated by the role of capital and social which has a higher role, but from the three variables the role of social variables has the most dominant influence on entrepreneurial success as indicated by the highest standardized beta figures such as in table 2 .

The next test is the Simultaneous Hypothesis Test, which is to test the magnitude of the influence of all independent variables simultaneously on the dependent variable. The results of hypothesis testing with the F test calculated using the SPSS program can be seen in table 3 .

Table 3. Test F Analysis

\begin{tabular}{llrrrrr}
\hline \multicolumn{7}{c}{ ANOVA $^{\mathrm{a}}$} \\
\hline \multirow{2}{*}{ Model } & & Sum of Squares & Df & Mean Square & F & \multicolumn{1}{c}{ Sig. } \\
\hline \multirow{2}{*}{1} & Regression & 135,540 & 3 & 45,180 & 30,487 &, $000^{\mathrm{b}}$ \\
\cline { 2 - 7 } & Residual & 71,133 & 48 & 1,482 & & \\
\hline
\end{tabular}




Total 206,673 51

Source: The results of the study were processed using SPSS 23

F-test is done to find out whether the three variables consisting of Human Capital, Social Capital, and Competence as simultaneously have a significant effect on Entrepreneurial Success. As we can see in table 3 that the F value shows a number of 30.47 and a significant probability of 0.000 means that Human Capital, Social Capital, and Competence simultaneously have a significant effect on Entrepreneurial Success. This can be indicated that to become a successful women entrepreneur must pay attention to human resources that are well managed such as human capital, has a social ability and high competency.

\section{Conclusion}

Based on several analysis in this study, it can be concluded and recommended several things as follows:

Human Capital, Social Capital, and Competence Simultaneously have a significant effect on entrepreneurial success. But partially human capital and social capital have a significant effect on entrepreneurial success, nevertheless for the competency variable it has no significant effect on entrepreneurial success. This implies that as an entrepreneur, it should prioritize the ability of social capital and human capital to achieve success because these two variables significant influence on entrepreneurial success. For further researchers it is recommended to conduct research on the role of competency on entrepreneurial performance which is the research gap of this research.

\section{References}

[1] T. H. Alnachef and A. A. Alhajjar, "Effect of Human Capital on Organizational Performance: A Literature Review,” Int. J. Sci. Res., vol. 6, no. 8, pp. 2319-7064, 2015.

[2] J. D. Schermerhorn, G. H. James, and N. O. Richard, Organizational Behaviour. New Jersey: John Willey and Son Inc, 2005.

[3] D. P. Dimova and D. A. Shepherd, "Human capital theory and venture capital firms: exploring ' home runs' and Strike outs"," J. Bus. Ventur., vol. 20, pp. 1-21, 2010.

[4] P. Moody, J., \& Paxton, "Building bridges linking social capital and social networks to improve theory and research introductio," Am. Behav. Sci., vol. 52, pp. 1491-1506, 2009.

[5] G. D. Markman, Robert A. Baron, "Beyond social capital: the role of entrepreneurs' social competence in their financial success," J. Bus. Ventur., pp. 41-60, 2008.

[6] S. Mujanah, T. Ratnawati, and A. Kusmaningtyas, "The effect of competence, emotional quotient, and financial quotient on the business performance of small and medium enterprises in Surabaya, Indonesia," in Proceeding of 16th International Symposium on Management, 2019.

[7] J. M. Unger, A. Rauch, M. Frese, and N. Rosenbusch, "Human capital and entrepreneurial success: A meta-analytical review," J. Bus. Ventur., vol. 26, no. 3, pp. 341-358, 2011.

[8] C. J. L. Gaol, A to Z Human Capital (Manajemen Sumber. Jakarta: PT. Gramedia Widiasarana, 2014.

[9] G. S. Becker, Human Capital: a theoretical and empirical analysis, with special reference to education. London: The University of Chicago Press, Ltd, 1993. 
[10] E. U. Choudhri and D. S. Hakura, "International trade and productivity growth: exploiting the sectorola effets for developping countries," IMF Staff Pap., vol. 47, no. 1,2000

[11] P. C. Nugraha, H. Susilo, and E. K. Aini, "Pengaruh Human Capital terhadap Kinerja Perusahaan (Studi pada Perusahaan Advertising dan Periklanan Malang yang Terdaftar pada Asosiasi Advertising dan Periklanan Malang)," J. Adm. Bisnis, vol. 57, no. 2, 2018.

[12] R. D. Putnam, Democracies in Flux: The Evolution of Social Capital in Contemporary Society. Oxford: Oxford University Press, 2002.

[13] P. Bourdieu, Arena Produksi Kultural. Yogyakarta: Kreasi Wacana, 2015.

[14] A. E. Yustika, Ekonomi Kelembagaan Paradigma, teori dan Kebijakan. Jakarta: Erlangga, 2013.

[15] E. Cox, A Truly Civil Society. Sidney: ABC Books, 1995.

[16] J. Hasbullah, Social Capital: Menuju Keunggulan Budaya Manusia. Jakarta: MRUnited Press, 2006.

[17] J. Coleman, "Social Capital in the Creation of Human Capital," Am. J. Sociol., vol. 94, pp. 95-120, 1999.

[18] G. Liu, J., Qu, H., Huang, D., Chen, "The Role of Social Capital in Encouraging Residents' Pro-Environmental Behaviors in Community-Based Ecotourism," Tour. Manag., vol. 41, pp. 190-201, 2014.

[19] M. Fauzan, "Peningkatan kinerja dosen berbasis modal sosial dan dukungan organisasional di PTS Kota Semarang,” J. Bisnis dan Ekon., vol. 19(2), pp. 188-202, 2012.

[20] F. Fukuyama, "Sosial Capital: Civil Society and Development," Third World Q., vol. 22, 2001.

[21] Wibowo, Manajemen Kinerja. Jakarta: PT. Raja Grafindo Parsada, 2007.

[22] P. dan N. T. Hutapea, Kompetensi Plus: Teori, Desain, Kasus dan Penerapan untuk HR dan Organisasi yang Dinamis. Jakarta: Gramedia Pustaka Utama, 2008.

[23] Suparno, Pengaruh Kompetensi, Motivasi kerja, dan Kecerdasan. Bandung: Alfabeta, 2005.

[24] N. H. Ahmad, T. Ramayah, C. Wilson, and L. Kummerow, "Is entrepreneurial competency and business success relationship contingent upon business environment? A study of Malaysian SMEs," Int. J. Entrep. Behav. Res., vol. 19, no. 3, 2010.

[25] E. Sihombing, "Pengaruh Kompetensi Wirausaha dan Lingkungan Bisnis terhadap Kesuksesan Wirausaha pada Usaha Kecil (Studi Kasus Pada Bisnis Ritel di Wilayah Jakarta Timur)," Universitas Indonesia, 2013.

[26] L. Holbeche, The High Performance Organization: Creating dynamic stability and suistainble succsess. Oxford: Elsevier Butterworth-Heinemann, 2005.

[27] A. Mayo, "The Role of Employee Development in The Growth of Intellectual Capital," Pers. Rev., vol. 29, no.4, 2000. 